УДК $821.111-3$

\title{
О. О. Бойко
}

аспірантка кафедри прикладної лінгвістики

Одеського національного університету імені I. І. Мечникова

\section{РЕФЕРЕНЦІЇ ЯК ЗАСІБ СТВОРЕННЯ ЦІЛСНОГО ЦИКЛУ (НА МАТЕРІАЛІ ОПОВІДАНЬ НІКІ КАЛЛСН)}

\begin{abstract}
У статті проаналізовано функиію референційних інтертекстуальних посилань i їхню роль у створенні иілісного цииклу фентезійних оповідань. Представлено різноскеровані думки наукової спільноти з приводу термінологічного уналежнення референцій. Висунуто гіпотезу, що референиії як різновид інтертекстуальних елементів виконують функиію покликань між творами одного автора, зокрема, у статті наведено класифікацію різновидів референцій в оповіданнях Нікі Каллєн. Продемонстровано, шчо референиії є елементами внутрішньої інтертекстуальності, проте вони не є простими покликаннями на інший текст, а збільшують питому вагу «реальності» того чи іншого твору з допомогою повторюваних онімів на позначення «наскрізних» персонажів, локацій, артефактів, які переплітаються один з одним і перегукуються. Аргументовано, щзо використання референцій сприяє створенню множинних світів, щзо входять до єдиного Мультиверсуму, зображеного автором. Показано, щчо засвідчені референції дають змогу створити комунікативну ситуаџію, в якій вигадане поєднується з наявним у реальності читача, щчо наближує можливий, паралельний світ до «нашого». Такі посилання є упізнаваними й насиченими енергією інтертекстуальності, своєрідними інформаційними хабами - розподільниками інформації, якщз проводити аналогію з комп'ютерними технологіями. Перспективним постає подальше дослідження фентезійних творів, зокрема, за авторства Нікі Каллєн, із розмежуванням понять «паралельні світи» та «множинні світи».
\end{abstract}

Ключові слова: фентезі, референиії, Нікі Каллєн, інтертекстуальність, можливі світи, Мультиверсум.

Постановка проблеми. Термін «референція» $є$ багатозначним і використовується в багатьох галузях знання, у тому числі в лінгвопрагматиці та в теорії інтертекстуальності. Навіть у лінгвістиці це поняття має різноскероване наповнення. Референція як об'єкт дослідження поставала в наукових розвідках українських (Т. Динниченко, А. Загнітко, Ю. Лосєва тощо) і закордонних (Н. П'єге-Гро, М. Пфістер, Ф. Ріффатер тощо), проте на сьогодні не існує дослідження референцій у фентезійному дискурсі, зокрема, зовсім відсутні наукові розвідки, присвячені вивченню творчості Нікі Каллєн та інтертекстуального аспекта в його творах, а також концепції можливих світів та Мультиверсуму в циклі його оповідань, що й зумовило актуальність дослідження. 
Аналіз наукових досліджень. А. П. Загнітко визначає референцію як «процес співвідношення одиниць мовлення (іменників та іменної групи) з позамовною дійсністю, а також результат такого співвідношення. (...) Під референцією здебільшого розуміють відношення актуалізованих іменних висловів до реального або уявного світу, а під референтом - об'єкт, на який вказує цей вислів. Завдяки відношенням вказівки, позначення та номінації, які є опертям референції, забезпечується зв'язок між мовою й іншими реаліями» [3, с. 40] У світлі цієї теорії референції можуть бути означеними, неозначеними або нульовими.

Точний переклад слова reference означає «покликання, співвідношення», отже, термін «референція» використовується також у теорії інтертекстуальності. Проте варто зауважити, що подекуди цей термін використано на позначення посилання, покликання загалом, пор.: «Інтертекстуальність - це референція до інших текстів чи дискурсів, що проявляється в плані змісту чи плані вираження» [7]. Гоголіна В. В. уналежнює референції до властивостей свідомості читача: «спроєктувати на текст власні референції» [8], Худолєй Н. В., базуючись на розвідках Н. П’єге-Гро, ототожнює поняття референції та ремінісценції [15].

Найближчою для нашої розвідки є позиція Н. П'єге-Гро. Дослідниця уналежнює посилання-референцію, як і цитату, до експліцитних форм інтертекстуальності: «в цьому випадку текст, на який покликається автор, безпосередньо не $є$ присутнім у його власному тексті. (...) Наприклад, Бальзак використовує покликання для створення враження багатократного перегукування між різними романами» [12, с.83] Далі Н. П'єге-Гро наводить приклад із «Луї Ламбера», де внутрішні міжтекстові покликання набувають першочергового значення: «Найголовніше полягає в тому, що це покликання дає хід складній грі між вигадкою та реальністю, оповідачем і автором, адже ії функція не вичерпується вказівкою на родинний зв'язок між двома вигаданими персонажами; з ії допомогою Луї Ламбер постає реальним взірцем для іншого персонажа» [12, с. 91].

Т. Динниченко також бере за основу ідею Н. П'єге-Гро, і у своєму дисертаційному дослідженні акцентує: «референцією в літературознавстві називають згадку про цілий твір або одного з героїв (в іншій термінології -«точкова» цитата або «згорнутий текст»)» $[9$, с. 81$]$.

Наше дослідження референцій у творах Нікі Каллєн грунтується на тому, що референції є елементами внутрішньої інтертекстуальності, проте вони не $\epsilon$ простими покликаннями на інший текст, а збільшують питому вагу «реальності» того чи іншого твору, адже перед нами постають повторювані оніми на позначення «наскрізних» персонажів, локацій, артефактів, які переплітаються один $з$ одним і перегукуються. Ці переплетення, на нашу думку, дають змогу говорити про те, що оповідання Нікі Каллєн лежать у площині лінгвістичного аспекту теорії можливих світів. Окрім того, вигадані антропоніми, в тому числі поетоніми, міфоніми, хороніми, астіоніми наводяться в одному контексті 3 реальними для читача прецедентними феноменами - іменами, артіонімами (прецедентними назвами) тощо. Створено комунікативну ситуацію, в якій ви- 
гадане поєднується з наявним у реальності читача, що наближує можливий, паралельний світ до «реального», «нашого».

Проблематику теорії можливих світів у лінгвістиці було актуалізовано в працях українських дослідників (І. Александрук., О. Кагановська, О. Котовська, Т. Нікульшина, I. Разумович тощо). Термін «можливі світи» було вжито вперше в роботах Г. В. Лейбніца, у подальшому концепцію розробляли в модальній логіці (Л. Вітгенштейн, Я. Хінтіка тощо), в теорії дискурсу (Ф. Бацевич, І. Бехта, В. Карасік тощо). Поширення теорії дискурсу дало змогу включити концепцію до філологічного вжитку. Зокрема, дотичною до проблематики нашого дослідження $є$ наукова розвідка I. Александрук, яка аналізує вербалізацію можливих світів у жанрі фентезі на матеріалі творів сучасних англійських та американських авторів [1]. В роботі було проаналізовано лексичні номінативні одиниці (неологізми, оказіоналізми), речення та паремії. І. Александрук стверджує, що «можлива картина світу - це ментальний конструкт, який має індивідуальний та антропоцентричний характер... Основними концептуальними категоріями МС постають ЛЮДИНА, ЧАС, ПРОСТІР, КУЛЬТУРА, ПРИРОДА, СУСПІЛЬСТВО, АРТЕФАКТ» [1, с. 4].

О. Котовська порівнює нецентровану та центровану моделі можливих світів. За словами дослідниці, центрована модель базується на твердженні Д. Льюїса про те, що «кожен можливий світ - це альтернативний конкретний світ, який $\epsilon$ актуальним та реальним із погляду його мешканців» [10], а нецентрована - на ідеї нескінченної множини світів, «які можуть взаємодіяти між собою, що дає можливість кожному можливому світу бути пов'язаним із певною кількістю інших різноманітних світів» [10]. Зокрема, віртуальний фентезі-світ, як зауважує О. Котовська, є уявним і нереальним, «однак, внаслідок функціонування в ньому традиційних концептів-міфологем, він є відомим, знайомим, а тому й відносно реальним» [10]. Те, що ми називаємо множинними світами, у роботі О. Котовської постає як «альтернативні»: «коли оповідання... торкається деяких варіацій у самому тексті для того, щоби створити альтернативні вигадані світи» [10].

I. Разумович актуалізує функцію паратексту як засобу вербалізації можливих світів [13]. Зокрема, досліджено роль авторського перітексту (епіграфів, вступів, коротких передмов до розділів або додатків до попередніх розділів) у романі «The Eyre Affair» Дж. Форде. Дослідниця акцентує увагу на тому, що моделі можливих світів характерні для різних типів дискурсу, зокрема, наукового та публіцистичного.

В дослідженні Я. Сазонової проаналізовано роль референцій у створенні текстів дискурсу жахів, в іiі роботі увагу акцентовано на розумінні референції як «інструменту актуалізації світу, тобто як засобу його творення, що робить дійсним будь-який світ, навіть вигаданий світ художнього дискурсу...» [14]. Зауважимо, що дослідниця послуговується поняттям референції як когнітивного засобу, і вважає, що референція в художньому дискурсі «спирається на сформо- 
ваний емоційний та інтелектуальний досвід адресанта й адресата і формується на основі когнітивних моделей реального світу» [14]. Такий підхід уналежнює референції до прямих покликань на реальний досвід читача; в нашому розумінні такі покликання є ремінісценціями.

Отже, поняття можливих світів не $є$ однозначним - про це свідчить кількість синонімів із одного семантичного ядра, але різних за змістом: віртуальні, паралельні, множинні, альтернативні тощо. В нашому дослідженні можливі світи постають у двох варіантах: як множинні (такі, що відрізняються один від одного фізичними законами, назвою тощо) і паралельні (неосяжна кількість варіацій одного й того «реального» світу, розвиток історії якого відрізняється в кожній точці біфуркації). Паралельні світи, на нашу думку, входять до одного Мультиверсуму.

Мета статті полягає у започаткуванні серії досліджень творчості Нікі Каллєн в аспекті вивчення інтертекстуальних та інтердискурсивних елементів у фентезійному дискурсі циклу оповідань автора. В актуальній розвідці мета постає більш конкретною: аргументувати розуміння референції як інтертекстуального елемента, що пов'язує твори одного автора між собою, засвідчити i проаналізувати референції, наявні в нині оприлюднених оповіданнях Нікі Каллєн. Постановка мети сприяла визначенню низки завдань: картографувати всі наявні в оповіданнях референції, проаналізувати кількість «вхідних» та «вихідних» референцій, визначити їхні різновиди і функції у створенні цілісного циклу оповідань.

Ілюстративною базою для нашого дослідження постали оповідання Нікі Каллєн із трьох збірок: «Гель-Грин. Город в центре Земли», «Арена» й «Рассказы о Розе. Side A». Всього було опрацьовано 17 оповідань, у них віднайдено 127 референцій.

Виклад основного матеріалу. Під час обробки оповідань ми використовували можливості текстового процесора Scrivener. На основі отриманих даних було створено таблицю (Рис.1), що ілюструє співвідношення «вхідних» та «вихідних» референцій. У лівому стовпчику таблиці наведено перелік тек iз референціями, що $\epsilon$ «вхідними», тобто в цих теках розміщено фрагменти 3 інших оповідань, які покликаються на конкретне оповідання. Наприклад, на першому місці - «Братство Розы», 20 вхідних референцій. У правому стовпчику - «вихідні», там містяться фрагменти з одного оповідання, що відсилають до інших. Так, в оповіданні «The Chauffeur» віднайдено 18 референцій на інші оповідання з трьох збірок (див. рис. 1).

Визначимо центральні та периферійні оповідання в циклі. Підсумовуючи кількість «вхідних» та «вихідних» референцій, ми можемо визначити 3 центральних і 14 периферійних оповідань у системі. До центральних уналежнюємо такі: «The Chauffeur» (28), «Братство Розы» (27), «New Religion» (17). Найбільш віддаленими від «ядра» $є$ оповідання «Wild Boys» (6), «Руанский собор ночью» (6) та «Дикий сад» (4). 


\begin{tabular}{|c|c|c|c|c|}
\hline 4 Н Никки Каллен вхідні & ○田 & 4 & - & บ8 \\
\hline Название & Краткое содерж & \multicolumn{3}{|c|}{ Название } \\
\hline Братство Розы 20 & $\Delta$ & \multicolumn{3}{|c|}{ Whe Chauffeur 18} \\
\hline D1) Трое и река 12 & & \multicolumn{3}{|c|}{ W Planet Earth 12} \\
\hline DW Воспоминания о корабля... & & \multicolumn{3}{|c|}{ W Save a Prayer 11} \\
\hline The Chauffeur 10 & & \multicolumn{3}{|c|}{ II New Religion 10} \\
\hline The Seventh Stranger 8 & & \multicolumn{3}{|c|}{ D Union of the Snake 8} \\
\hline Ночь в белом бархате 7 & & \multicolumn{3}{|c|}{ D 13 Careless Memories 7} \\
\hline New Religion 7 & & \multicolumn{3}{|c|}{ DL Братство Розы 7} \\
\hline D Union of the Snake 7 & & \multicolumn{3}{|c|}{ IV The Seventh Stranger 7} \\
\hline Hungry like the Wolf 6 & & \multicolumn{3}{|c|}{ Р Руанский собор ночью 6} \\
\hline D) 13 Мельница и часы 6 & & \multicolumn{3}{|c|}{ DU Воспоминания о кораблях 5} \\
\hline W Is there something I should... & & \multicolumn{3}{|c|}{ D 13 Мельница и часы 4} \\
\hline Save a prayer 5 & & \multicolumn{3}{|c|}{ D 13 Трое и река 3} \\
\hline Wild Boys 3 & & \multicolumn{3}{|c|}{ W Is there something I should know? 3} \\
\hline D) Дикий сад 1 & & \multicolumn{3}{|c|}{ Wild Boys 3} \\
\hline Planet Earth 1 & & \multicolumn{3}{|c|}{ D 13 Дикий сад 3} \\
\hline D Careless Memories 1 & & \multicolumn{3}{|c|}{ D 13 Hungry like the Wolf 2} \\
\hline D T. Кафе "Красная мельня" 8 & & \multicolumn{3}{|c|}{ 1) Ночь в белом бархате 1} \\
\hline D 1 Красная лампа в форме г... & & \multicolumn{3}{|c|}{ D Кафе "Красная мельня" 8} \\
\hline & & \multicolumn{3}{|c|}{ \. Красная лампа в форме губ Мэй Уэст 3} \\
\hline
\end{tabular}

Рис.1. Таблиця зіставлення «вхідних» та «вихідних» референцій

Показовим є співвідношення в оповіданнях «вхідних» та «вихідних» референцій. Ми припускаємо, що оповідання, які мають переважну кількість «вихідних» референцій, є своєрідними об'єднувальними ланками між оповіданнями, певними «посередниками». До таких уналежнюємо, наприклад, оповідання «Planet Earth», що має одне «вхідне» покликання в оповіданні «Careless memories»: У него были отдельные блокноты для сюжетов. Про летающих девушек в красных платьях... (Careless Memories) - пор. в «Planet Earth»: "А я-Милана Эрнестина...я тоже летаю...... Все глазели на них: Милана громко смеялась, такая незнакомка, в красном платье к тому же и с коралловыми бусами...". Натомість це оповідання має 12 «вихідних» референцій на 7 інших оповідань.

Оповідання «Careless Memories» має також одне «вхідне»:... заиграл оркестр; арию «Una furtiva lagrima» из «Любовного напитка» Доничетти; дирижировал очень молодой парень - в смокинге, взъероменный, носатый, красивый, нервный; «о, - сказал Ричи, - ну надо же, они Даниэле Эко к себе затащили... он сумасшедший; может пюпитр сшибить, все листы летят по оркестровой яме... он гений (Братство Розы) - пор.: ... это Даниэле Эко, - сказал Снег, - я читал про него, ему двадиать четыре, как тебе; он гений... главный приглашённый дирижёр здесь и ешё в пяти оркестрах... Даниэле был мокр и прекрасен: длинный нос... (Careless Memories). Спостерігаємо повторювані лексеми, що сприяють впізнаваності персонажа: антропонім “Даниэле 
Эко”, його характеристика як “генія”, а також характерна риса “длинный нос", “носатый”. Акцентовано увагу на молодому віці персонажа: “очень молодой”, “ему двадцать четыре”. Зауважимо, що у фрагменті наведено прецедентні назви арії та опери, а також прецедентне ім'я композитора Доніцетті.

В цьому оповіданні 7 «вихідних» покликань, 3 з них відсилають до персонажа на ймення Стівен Леві. Стівен Леві з'являється в щоденниках, що читає Беріл - героїня оповідання «Union of the Snake». В «Careless Memories» роман про Стівена пише Макс: я пишу его дневник - он старомодный такой, в стиле восемнадцатого века... Окрім референції на «Careless Memories», у тексті щоденника в оповіданні «Union of the Snake» 3'являється й покликання на сюжет оповідання «The Seventh Stranger», у якому йдеться про Чорного колдуна й короля-ворона.

Оповідання, на які покликається більшість інших текстів у циклі, є більш реальними у всесвіті цього циклу або навпаки - постають популярними казками або легендами, тобто існують у паралельних світах, на різних рівнях реальності. До таких уналежнюємо легенду про Тревіса - короля морів, що оповідається в тексті «Ночь в белом бархате», казку про Менільєн - оповідання «The Seventh Stranger», сон або легенду про квітку, що розподіляє місто надвоє («Union of the Snake») й існування Братерства Троянди та його лицарів. В оповіданні «Воспоминания о кораблях» йдеться про заснування міста Гель-Грін та його перших жителів, а отже, на нього маємо 11 покликань із різних оповідань.

Розглянемо типи референційних зв'язків, що $є$ найчастотнішими в книгах Ніккі Каллєн. Тексти й паралельні всесвіти, у яких існують персонажі, можуть пов'язуватися один із одним через персонажа, місце або предмет (артефакт). Схожість, ідентичність світів ми відслідковуємо завдяки повторюваності лексичних маркерів, що слугують для характеристики артефактів, місць та персонажів. Зокрема, відбувається зміна онімів: в одному оповіданні ім'я $є$ антропонімом (персонаж є “реальним"), в іншому постає поетонімом або міфонімом. В оповіданні «Save a Prayer» імена Кая, Венери та їхнього сина є поетонімами:... третья повесть - «Замороженный», которую он не читал... О парне по имени Кай, как у него умерла жена, Венера, и остался ребёнок-мальчик по имени Руди; и Кай всё никак не может заплакать, ходит, ходит по городу, в котором собирается первый снег... (Save a Prayer) в «The Seventh Stranger» i в «New Religion» - антропонімами: у Венеры смешной маленький ребёнок, мальчик Руди (The Seventh Stranger); ...был женат на девушке неземной краcoтыl, с неземным именем - Венера - и воспитывал с ней общего ребёнка мальчика Руди... (New Religion)

Аналіз оповідань «The Seventh Stranger» та «The Chauffeur» дав змогу дійти висновку, що в них чітко відображено ідею Мультиверсуму. Про це свідчать повторювані лексеми, звороти, цілі речення. «The Seventh Stranger» $\mathrm{i}$ «The Chauffeur» не $є$ хронологічно поєднаними - зв'язок між ними відслідковується 3 допомогою двох персонажів: водія на дивній автівці і принца-самогубця в довгому плащі. 
Вважаємо невипадковим те, що ці два оповідання йдуть одне за одним у книзі, так само, як композиції в альбомі «Арена». В них показані різні варіанти розвитку однієї й тої самої події: аварії під час самогубства принца Лукаша. «The Seventh Stranger» закінчується таким чином: водій у машині їде сам, під час аварії гине лише принц Лукаш: ...из-за угла вылетела чёрная лакированная машина, странная, длинная, хромированная, под начало века... на скорости...... «Что случилось?» - спрашивал водитель; Клавдия подняла голову и увидела, что он молодой, красивый очень, черноглазый, невероятные чёрные глаза, мрачные, готические, без дна и жизни, будто озёра из Эдгара По; и он в шофёрской форме...

Лексеми, присутні в описі машини і водія, підкреслюють те, що це саме той водій і та машина, що і в оповіданні «The Chauffeur»: увидел такси, стильное, словно ночное джазовое кафе... - чёрная хромированная машина под сороковые годы... таксист оказался молодым и красивым - странной, мрачной, готичной красотой, из рассказов Эдгара По... белое личо, черные глаза...

В оповіданні «The Chauffeur» водій «таксі» Крістіан їде зі своєю дівчиною Лів на машині святкувати Різдво, на дорогу вибігає самогубець:... и тут на дорогу выскочил какой-то парень... «самоубийца», - подумал Кристиан, нажал на тормоза... Кристиан увидел, что он в странной одежде - старинной: не в пальто, шапке, джинсах, а в длинном коричневом плаще с капюшоном, $u$ меч у него за спиной... а потом машина... упала и загорелась, но они уже умерли... Наведемо також опис зовнішності принца, який віднаходимо в оповіданні «The Seventh Stranger»: ...одет он был в неотбелённую льняную рубашку... назад откинут длинный бархатный плащ цвета молочного шоколада, с длинным широким капюшоном... под плащом угадывался меч (The Seventh Stranger). Зауважимо, що автор використовує синонімічні звороти: “коричневый плащ”, “плащ цвета молочного шоколада” тощо. Отже, Крістіан і Лів загинули. Попри те, що в «The Seventh Stranger» не згадується ім’я водія, а в «Тhe Chauffeur» - ім'я самогубця, опис їхньої зовнішності, повторювані лексеми на позначення одягу та автівки дають змогу точно сказати, що це одні й ті самі персонажі, проте в одному оповіданні водій залишається живим, в іншому гине разом зі своєю дівчиною.

Персонажі $є$ важливою ланкою референційного зв'язку. Одні й ті самі персонажі можуть бути центральними або периферійними, вигаданими або реальними (відносно реальності подій в оповіданні). В оповіданнях Нікі Каллєн використано імена або імена 3 прізвищами, коли необхідно актуалізувати належність до роду і підкреслити зв'язок персонажів з різних оповідань (напр., Каролюс Дюран, Макс Дюран де Моранжа; Артур Сеттерфілд, Едвард Сеттерфілд тощо). Однак автор завжди використовує не тільки антропоніми, а й часто наводить детальний і дослівний опис їхньої зовнішності або особливостей життя, завдяки чому можна підтвердити ідентичність персонажів. Зокрема це стосується випадків, коли ім'я не вказано. Найупізнаванішими є назви про- 
фесій (капелан, священник), зовнішність (очі, одяг), характер. Проаналізуємо функцію, яку виконує персонаж Каролюс, який в певних оповіданнях постає святим.

Св. Каролюс (покровитель Братства Троянди, персонаж оповідання «Трое и река») (8 згадок). Найчастотнішими є непрямі ознаки його присутності: буруни або блиск на воді:... как кто-то любит смотреть на солнечные блики на воде - будто кто-то бежит - Биче Сениэль, святой Каролюс... (Братство Розы);... смотреть на рябь, будто не ветер, а Биче Сениэль бежит по воде, святой Каролюс Дюран шагает... (Seventh Stranger); (The Chauffeur). Супроводжуваним артефактом Каролюса є троянди, які виростають із його кроків:... и из каждого его шага вырастает огромная красная роза, и скоро всё поле полно роз, благоухающих, как разбитый флакон с розовым маслом на солние... (The Chauffeur). У наведених вище фрагментах з'являються оніми: поетонім О. Гріна «Біче Сеніель» («Та, що біжить по хвилях») з однойменного оповідання. Прецедентне ім'я «Біче Сеніель» є одним із багатьох елементів зовнішньої інтертекстуальності, якими насичені всі тексти з циклу. Частотним $є$ агіонім «святий Каролюс (Дюран)» - інколи з включенням прізвища. За визначенням Н. В. Подольської, агіонім є власним іменем святого [11, с. 124-125]; I. В. Бугаєва розширює класифікацію агіонімів до «словосполучення, яке служить для іменування осіб або об'єктів, на яких спочиває благодать Божа через чин прославлення або освячення» [2]. У такому випадку ім'я Каролюса постає агіоантропонімом. Окрім того, у повісті «Братство Розы» знаходимо короткий опис того, ким став Каролюс після закінчення історії з оповідання «Трое и река»:... развернул газету - и обомлел: на первой полосе был тот самый парень из сна, рыцарь Жанны д’Арк; «Каролюс Дюран канонизирован. Розовый святой» -и рассказывалось о том, кто он такой - капеллан, военный священник, он умер семь лет назад, убит на Святой войне... (Братство Розы). Майже дослівний текст з'являється наприкінці оповідання «Трое и река»: $B$ год, когда нам исполнилось двадцать семь, совсем молодые еще вроде, а вже столько всего случилось, я услышал... о смерти Каролюса; его убили на войне, он был католическим священником, военным священником - капелланом; а потом, через еще семь лет, его признали святыл. Отже, крім іншого, можемо зробити висновок, що події, описані в «Братстве Розы», відбуваються через сім років після закінчення оповідання «Трое и река» й через дев'ять років після подій у ньому: на той момент оповідачеві було 18:... восемнадцатилетний мальчик курил и кутался в свитер, и думал обо всем... (Трое и река).

Розглянемо тепер референційну роль місця, локації. Вважаємо локації важливими точками з'єднання різних оповідань. Незважаючи на те, що опис локацій не $є$ частотним, ми можемо навести чотири місця, які виступають референційними вузлами в різних оповіданнях. Подекуди локації актуалізовано через поєднання урбаноніма з ключовими лексемами опису, інколи - тільки через опис, який найчастіше містить прецедентні феномени (імена акторів та письменників). 
Найбільш частотною - 8 разів - $є$ поява урбаноніма кафе «Червоний млин» (варіанти оніма в різних Всесвітах та оповіданнях: Красная Мельня або Мулин Руж). Назва $є$ прецедентною і відсилає до кінострічки режисера База Лурмана «Мулен Руж». Здебільшого це кафе $є$ реальним у світі персонажів, лише одного разу про нього згадується, як про мрію:... открою, как повзрослею, кафе - такое, в подвале, красный кирпич, арки, камин, репродукции Тулуз-Лотрека на стенах, где всё будет демократично, вкусно и дешёво, и танцы ирландские по вторникам и воскресеньям... (Wild Bоys). Описується часто дослівно, основні ознаки - червона цегла, дерев'яні арки, комин, розташоване в підвалі, а також обов'язково прецедентний феномен - репродукції Тулуз-Лотрека: ... а девушка с волосами ивета луны осталась стоять у входа в кафе - чёрная лестница вниз: подвал со стенами из красного кирпича; ненастоящий Тулуз-Лотрек над настоящим камином... (Мельница и часы), ...Тео нужно было в «Красную Мельню», кафе недалеко от дома - краснокирпичный подвал с репродукциями Тулуз-Лотрека на стенах и настоящим камином... (Братство Розы) та ін.

Використання схожих або ідентичних локацій не $є$ точним підтвердженням того, що персонажі перебувають в одному Всесвіті - як було продемонстровано, герої можуть перетинатися в різних світах, які відрізняються тільки незначними деталями. В цьому випадку ключові локації, зокрема, кафе «Мулин Руж», $€$ своєрідним «якорем» для мандрівника між світами, проте варіації урбаноніма можуть відрізнятися. Розмитість меж реальностей, світів створює можливості для авторської гри, для накладання однієї реальності на іншу, так само, як сам автор постулював це в оповіданні «New Religion».

Найменш частотними, проте не менш актуальними для нашого дослідження $€$ референції з допомогою артефактів. Артефакти, в нашому розумінні, це певні предмети, що згадуються в різних оповіданнях і можуть належати різним людям - ми вважаємо їх незалежними, «мандрівними» (червона лампа). Здебільшого «мандрівні» артефакти не мають власних назв (хрематонімів) і можуть бути ідентифіковані лише за описом, що містить ключові лексеми.

Інші артефакти є покликаннями на різні оповідання. Напр., туфлі від Кароля Калиновського (3 згадки). Майже в усіх випадках їх опис супроводжується антропонімом дизайнера. Професія Кароля - дизайнер взуття - описана в першому оповіданні збірника «Арена»: - Я дизайнер, - сказал он, - придумываюю раз у год для одного знаменитого дома мод пару женских туфель, тем и живу, - а потом открыл шкаф-купе: полки от пола до потолка... женские туфли (Is there something I should know?) Таке взуття мимохідь згадується в оповіданні «Union of the Snake», і це єдине оповідання, у якому головній героїні пощастило носити взуття від Кароля: Это туфли одного молодого модельера, он делает только обувь, мои сёстры обожают его - Кароля Калиновского... (Union of the Snake). В оповіданні «Planet Earth» Мілана запевняє подругу, що чарівний пісок узбережжя, де живе Ангел, напрочуд ніжний:... мне мужчины не надо; даже туфель от Маноло Бланик, даже от Кароля Калиновского... 
(Planet Earth). В наведеному фрагменті використано частотний для Нікі Каллєн прийом поєднання поетоніма з реальним антропонімом: Маноло Бланік - дизайнер взуття, що існує в світі читача. В оповіданні «The Chauffeur» колекціонування взуття є мрією Едмунда:... буду жить в красной квартирке, собирать туфли... (The Chauffeur).

Червона лампа у формі губ Мей Уест: ...свет здесь шёл от монитора $u$ от красной лампы в форме губ Мэй Уэст... (Is there something I should know?) ...и вещии, которые имели для него значение, он рисовал: мамина лампа в форме губ... (Дикий сад), ...и лишь лампа на столике у дивана... была красной, в форме пышных женских губ (Мельница и часы). Лампа є вигадкою автора, натомість існує диван у формі губ, «під Далі», і знаходимо про нього одну згадку: ...диван под Дали, в форме губ Мэй Уэст... (New Religion). Концептуальне поле артефакту включає до себе одразу два прецедентних імені: американської акторки Мей Уест і художника Сальвадора Далі. Отже, лампа є вигаданим артефактом, а диван - реальним прецедентним феноменом, витвором мистецтва.

Перехрещення сюжетів оповідань із різних збірок, повторювані лексеми в описах зовнішності персонажів, локацій, дають змогу стверджувати, що оповідання Нікі Каллєн, зокрема «New Religion», «The Chauffeur», «The Seventh Stranger», а також інші, належать до т.зв. Мультивсесвіту, ідеї «можливих» або «множинних» світів.

Висновки і перспективи дослідження. Певні місця, персонажі й артефакти з'являються в різних оповіданнях частіше за інші. Вони є більш упізнаваними й насиченими енергією інтертекстуальності, своєрідними інформаційними хабами - розподільниками інформації, якщо проводити аналогію з комп'ютерними технологіями. Поміж таких локацій - кафе «Червоний млин» і “Зоряний пил”, Менільєн, персонажі - святий Каролюс, Тревіс, Олівер Рафаель, священик Артур Сеттерфілд, Кай; повторювані артефакти: червона лампа, квітка над містом тощо.

Ідентичність або тотожність визначається 3 допомогою онімів: поетонімів Нікі Каллєн, поєднаних з реальними для читача антропонімами, хоронімами, астіонімами тощо, а також із прецедентними феноменами - артіонімами (назвами витворів мистецтва) і антропонімами - прецедентними іменами. Зміну рівня "реальності" визначає перехід онімів з одного розряду до іншого: антропонім стає поетонімом або міфонімом, хоронім з вигаданого, казкового стає реальним (напр., Менільєн).

Окрім того, вкажемо на важливість концепції «можливих світів», яка відіграє неабияку роль у формуванні референційних зв'язків між сюжетами й персонажами в циклі оповідань Нікі Каллєн. Гра із рівнями реальності нагадує калейдоскоп, візерунок якого ніколи не повторюється. Ми вважаємо перспективним подальше дослідження фентезійних творів із розмежуванням понять «паралельні світи» та «множинні світи». До паралельних ми уналежнюємо саме ті, що підходять під еверетичну концепцію: один сюжет із безліччю точок 
розгалуження варіантів, до множинних - різні світи, наприклад, світи М. Фрая (Світ Стержня (Схо), Світ Павука (Земля), Хомана) Д. Корній (Світ Білих Вурдалаків, Світ Згаслого Сонця, Світ Сдиного Бога) тощо.

\section{Література}

1. Александрук I. В. Вербалізація можливих світів у жанрі фентезі (на матеріалі творів сучасних англійських та американських авторів): автореферат дис. канд. філол. наук. Харків, 2011. 18 c.

2. Бугаева И. В. Агионимы в православной среде: структурно-семантический анализ. Москва: ФГОУ ВПО РГАУ - МСХА им. К. А. Тимирязева, 2007. 138 с.

3. Загнітко А. П. Сучасні лінгвістичні теорії. Донецьк: ДонНУ, 2007. 219 с.

4. Каллен Никки. Арена. Санкт-Петербург: «Комильфо», 2010. 730 с.

5. Каллен Никки. Рассказы о Розе. Side А. Москва: АСТ, 2015. 544 с.

6. Каллен Никки. Гель-Грин, центр земли. Москва: Яуза, 2018. 288 с.

7. Лосєва Ю. В. Інтертекстуальність як основний композиційний принцип художнього дискурсу Джуліана Барнса (на матеріалі роману «Історія світу в 10 1/2 розділах») [електронний варіант]. Режим доступу: https://cutt.ly/bgOQrjY

8. Гоголіна В. В. Поетика біблійного інтертексту в «Києво-печерському патерику»: автореферат дис. канд. філол. наук. Львів, 2019. 18 с.

9. Динниченко Т. А. Типологія форм інтертекстуальності у французькій модерністській прозі (на матеріалі творів Андре Жіда): дис. канд. філол. наук. Київ, 2016. 210 с.

10. Котовська О. В. Типологія можливих світів у когнітивній лінгвістиці [електронний варіант] Режим доступу: https://cutt.ly/igOmCpV

11. Подольская Н. В. Словарь русской ономастической терминологии Москва: Наука, 1988. $192 \mathrm{c}$

12. Пьеге-Гро Н. Введение в теорию интертекстуальности. Пер. с фр, общ. ред. и вступ. ст. Г. К. Косикова. Москва: Изд-во ЛКИ, 2008. 240 с.

13. Разумович I. А. Паратекст як засіб вербалізації можливих світів в англомовному художньому текстопросторі (на матеріалі роману Дж. Ффорде «The Eyre Affair») [електронний варіант]. Режим доступу: https://cutt.ly/fgOmJBF

14. Сазонова Я. Ю. Типи референції в текстах дискурсу жахів. Лінгвістичні дослідження. 2016 Вип. 43. С. 208-216. Режим доступу: http://nbuv.gov.ua/UJRN/znpkhnpu lingv 20164330.

15. Худолей Н. В. Механизмы актуализации интертекстуальных связей в художественном тексте [электронный вариант]. Режим доступа: https://cutt.ly/MgOQiYW

\section{References}

1. Aleksandruk I V. Verbalization of possible worlds in the genre of fantasy (based on works by modern English and American authors). The dissertation on competition of a degree of the candidate of philological sciences... on a specialty 10.02.04. - Germanic languages. KhNU named after V. N. Karazin. Kharkiv, 2011. 18 p.

2. Bugaeva I. V. Agionyms in the Orthodox environment: structural and semantic analysis: Monograph. M .: FGOU VPO RGAU - MSHA im. K. A. Timiryazeva, 2007. 138 p.

3. Zagnitko A. P. Modern linguistic theories. Monograph. Kind. 2nd, ed. and ext. Donetsk: DonNU, 2007. 219 p.

4. Kallen Nicky. Arena. Saint-Petersburg: Komilfo, 2010. 730 p.

5. Kallen Nicky. Tales of the Rose. Side A. Moscow: AST, 2015.544 p.

6. Kallen Nicky. Gel-Green, the center of the earth. Moscow: Yauza, 2018. 288 p. 
7. Loseva Y. V. Intertextuality as the main compositional principle of the artistic discourse of Julian Barnes (on the material of the novel "History of the World in $101 / 2$ chapters") [electronic version]. Access mode: https://cutt.ly/bgOQrjY

8. Gogolina V. V. Poetics of scriptural intertext in "Kiev-Pechersk Paterik". Abstract of the dissertation for the degree of Candidate of Philological Sciences... in the specialty 10.01.01. - Ukrainian literature. Lviv, Ivan Franko Lviv National University, 2019. 18 p.

9. Dinnichenko T. A. Typology of forms of intertextuality in French modern prose (based on the works of Andre Zhida). The dissertation on competition of a degree of the candidate of philological sciences... on a specialty 10.01.05 - the theory of literature. Kiev, Kiev University named after Boris Grinchenko, 2016. 210 p.

10. Kotovska O. V Typology of possible worlds in cognitive linguistics [electronic version]. Access mode: https://cutt.ly/igOmCpV

11. Podolskaya N. V. Dictionary of Russian onomastic terminology / Editor-in-Chief AV Superanskaуа. - 2nd ed., Reworked. and ext. - М .: Наука, 1988. - 192 p.

12. Pieguet-Gro N. Introduction to the theory of intertextuality. Moscow: LKI Publishing House, $2008.240 \mathrm{p}$.

13. Razumovich I. A Paratext as a means of verbalization of possible worlds in the English-language artistic text space (on the material of J. Fforde's novel "The Eyre Affair") [electronic version]. Access mode: https://cutt.ly/fgOmJBF

14. Sazonova Ya. Yu. Types of reference in the texts of the discourse of horrors // Linguistic research. - 2016. - Vip. 43. - P. 208-216. - Access mode: http://nbuv.gov.ua/UJRN/znpkhnpu_ lingv_2016_43_30

15. Khudoley N. V. Mechanisms of actualization of intertextual links in a literary text [electronic version]. Access mode: https://cutt.ly/MgOQiYW

\section{Boiko O. O.}

\section{REFERENCES AS A MEANS OF CREATING AN INTEGRATED CYCLE (ON THE MATERIAL OF NICKY CALLEN'S STORIES)}

The article analyzes the function of "reference" - intertextual references and their role in creating a holistic cycle of fantasy stories and presents the diverse views of the scientific community on the terminological affiliation of references. It is hypothesized that references as a kind of intertextual elements perform the function of vocations between the works of one author, in particular, the article shows the classification of kinds of references in the stories of Nicki Callen. It is shown that references are elements of internal intertextuality, but they are not simple references to another text, but increase the share of "reality" of a work with repeated onyms to denote "through" characters, locations, artifacts that intertwine with each other. and resonate.

It is argued that the use of references contributes to the creation of multiple worlds that are part of a single Multiverse, depicted by the author. It is shown that certified references make it possible to create a communicative situation in which fiction is combined with the existing reality of the reader, which brings a possible, parallel world to "ours". They are recognizable and saturated with the energy of intertextuality, a kind of information hubs - distributors of information, by analogy with computer technology. Identity is determined by onyms: Nicki Callen's poetonyms, combined with real for the reader anthroponyms, horonyms, astonyms, etc., as well as with 
precedent phenomena - artionyms (names of works of art) and anthroponyms - precedent names. The change in the level of "reality" determines the transition of onyms from one category to another: an anthroponym becomes a poetonym or a mythonym, a choronym from a fictional, a fairy-tale becomes real (eg, Menillen).

Further research into fantasy works, in particular by Nicki Cullen, with a distinction between "parallel worlds" and "multiple worlds", is promising. To the parallel we belong exactly those that fit the heretical concept: one plot with many points of branching options, to multiple - different worlds.

Key words: fantasy, references, Nicki Kallen, intertextuality, possible worlds, Multiverse 